\title{
ADMINISTRATIVAS
}

\section{A Administração na República Federal da Alemanha}

(traduzido, sob o patrocinio do Instituto Brasileiro de Ciências Administrativas, da Revista Internacional de Ciências Adıninistrativas, Vol. XXV, $7^{2} 2,1959$ ).

$\mathrm{P}$ OR ocasião do XI Congresso Internacional de Ciências Administrativas, realizado pelo Instituto Internacional de Ciências Administrativas em Wiesbaden, Alemanha, de 31 de agôsto a 3 de setembro de 1959, dedicou a Revista Internacional de Ciências Administrativas o seu $n^{\circ} 2$ de 1959 à República Federal da Alemanha, publicando, na integra e em resumo, nove artigos. por autoridades de renome, sôbre as ciências administrativas naquele país.

Desnecessário será salientar a importância, para os professôres e estudiosos das ciências administrativas, da iniciativa da Revista Internacional. Basta dizer que, pela primeira vez, um grupo de especialistas se dedicou ao estudo comparativo das tendências administrativas da Alemanha Ocidental em confronto com as dos demais países.

No presente número da Revista do Serviço Püblico encontrarão os leitores cinco dêsses artigos, traduzidos dos respectivos resumos. No próximo número, serão publicados os quatro restantes.

\section{NOVAS TENDENCIAS DO DIREITO ADMINISTRATIVO ALEMAO}

por Fritz Werner, Presidente do Tribunal Administrativo Federal, República Federa' da Alemanha.

Quaisquer consideraç̃̃es sôbre as tendências atuais do Direito Administrativu, alemão devem, antes de tudo, incluir uma análise de suas relações com o Direito Constitucional, que condiciona de maneira considerável tanto os conceitos como a estrutura do Direito Administrativo. A Constituição "Federal distribui responsabilidades e competência entre a Federação e os "Länder", e essa distribuição define o escopo do direito administrativo. Ademais, a Lei Básica relaciona uma série de direitos humanos fundamentais, os quais devem ser respeitados pelas autoridades administrativas. Alguns dêsses princípios têm uma relação direta com os processos administrativos. igualdade perante a lei, liberdade de opinião e de profissão ou comércio, direito de propriedade, e assim por diante. Todavia, não inpedem êles um crescente intervencionismo estatal, sem nos esquecermos do fato de quie muitas vêzes não é nada fácil pôr em ação êsses principios. 
Os direitos constitucionais estão expressos em têrmos gerais e concisos, ao passo que as autoridades administrativas estão habituadas a agir de acôrdo com instruções explicitas. Não podem elas empregar, nesta matéria, os podêres discricionários, mesmo porque êsses são limitados pela constituição. A transposição, para a prática, dos principios consagrados pelos direitos fundamentais, demanda um grande impulso educativo dos funcionários, essencial ao desenvolvimento da administração.

O direito administrativo sofre igualmente a influência da idéia de Estado, tal como está expressa na Constituição. A República Federal Alemã é tanto um "Estado de direito" como "social" e ambas condições têm conseqüências muito grandes.

A tradicional noção alemã de "Estado de Direito" tende a restrinçir os poderes do Executivo. A conformidade à lei e a supremacia da lei são de capital importância. Cada ato administrativo deve ter a lei por base, e o poder discricionário jamais deve degenerar em arbitrariedade. Surge assim uma escala de padrões, com a lei por cume. Enquanto cidadãos privados podem levar a cabo qualquer atividade que não esteja legalmente proibida, o reverso é que é válido para as autoridades administrativas, as quais só se podem mover dentro dos liimtes que lhes indica a lei. As liberdades e a propriedade encontram-se protegidas contra o abuso do executivo, especialmente no que se refere às autoridades policial e fiscal.

Os podères policiais e fiscais continuam a ser o esteio da administração atual. Mas nuvitas das tarefas da administração baseiam-se no conceito social to Estado, noção essa bastante ampla e que repousa sôbre novos principios.

O contribuinte, ao mesmo tempo que proclama o seu desejo de ver reduzido o intervencionismo a um minimo, espera que o Estado interverha em muitas ocasiões. Tôda modificação que se verifica no setor administrativo reflete essa dualidade. De acôrdo com a teoria da adıninistração como promotora de serviçus, desenvolvida há apenas vinte anos por ERNST FoRSTHOFF, o poder públics desempenha tarefas, além de seus deveres tradicionais, com o fito de melhorar as condições sociais ("Daseinvorsorge"). Assim, o poder público proporciona o suprimento de água, gás e eletricidade, organiza o transporte público, proporciona facilidades econômicas, concede subvenções e auxílios para educação, etc.

A nova tendência do direito administrativo rapousa sôbre a diferença entre administração tradicional, chamada administração de intervenção ("Eingriffsverwaltung"), e a nova administração, chamada de administração de serviços ou de gestão ("Leistungsverwaltung" e "Lenkungsverwaltung".). Essa diferença nem sempre é mutito precisa, porquanto há um certo grau de superposição e interpenetração. Algumas decisões que tomam a aparência de "Eingriffsverwaltung", tais como portarias policiais, ou regulamentos fiscais, são na realidade, em vista de sua substância, quer atos de "Leistung" quer de "Lenkung". O direito administrativo alemão caracteriza-se em grande parte pela superposição que reina ente os tipos de administração. Por exemplo, o direito industrial transformou-se em direito econômico, a assistência pública em previdência social, a regulamentação 
de habitação, em direito de gestão dos espaços habitáveis, etc. A tendência é reforçada pelas exigências dos grupos interessados (e.g. danos de guerra, refugiados, ex-prisioneiros de guerra, etc.). As condiçóes peculiares que têm prevalecido na Alemanha desempenham um importante papel, embora não exclusivo, nesse desenvolvimento. A modificação gradual no conceito básico de Estado é outro fator importante. O direito administrativo atual apresenta, assim, um duplo caráter, de continuador do passado e iniciador do moderno direito.

Se o direito se modificou formalmente é isto devido a uma mudança no sentimento dos cidadãos para com o Direito e a Justiça. Enquanto desejam um campo para empreendimentos pessoais, livre da intervenção do Estado, advogam, entretanto, a responsabilidade do Estado para riscos sociais e compensações comunais por danos decorrentes de circunstâncias históricas excepcionais. Isto leva a uma extraordinária proliferação de disposições legais que regem a indenização. Ainda não se pode julgar do valor de tal transformação, e o único caminho aberto é tomar nota do fato corrente de que em várias instâncias as medidas legislativas seguiram-se à exigência popular de reparação de danos sofridos. Isto significa, igualmente, que o Estado se tem apossado de novos dominios e que os contrôles de sua ação, conseqüentemente, se multiplicam.

A posição atualmente adotada pelo Estado acarreta consequiências tanto financeiras como legais. Faz com que seu impacto seja sentido nas noções tradicionais, o que resulta em uma assimilação do direito administrativo no direito civil. O direito administrativo não é simplesmente a codificação das obrigações do direito público. Não obstante, muitos problemas têm origem na adoção de princípios ainda não explorados e nas dificuldades inerentes à sua aplicação. Várias instituições jurídicas exigem adaptação antes que possam ser aplicadas em administração. Estão nesse caso, por exemplo, as noções de direito civil como boa fé, prescrição ou a cláusula rebus sic standibus.

Outro tipo de conseqüência é a que afeta o exercicio do poder discricionário. Nas novas disposições legais formulam-se certos direitos e as autoridades são chamadas a implementar a lei automàticamente. Mas as mesmas disposições exigem também discrição para a aplicação de várias cláusulas gerais. O poder discricionário é aí implícito, no entanto, diferenie, en seus principios, daquele que anteriormente prevalecia. Os interêsses do contribuinte agora condicionam o ato administrativo, enquanto anteriormente o interêsse público era, senão a única, pelo menos a principal consideração.

O desenvolvimento da administração tem sido, lògicamente, acompanhado por novo refôrço da proteção legal ao cidadão. Teòricamente, a Lei Básica garante proteção por meio do direito geral de recurso a uma ação contendiosa contra o Estado. Côrtes e tribunais ganham conseqüentemente importância na estrutura do Estado. Eles não mais servem exclusivamente de contrôle do Executivo: são os guardiães do direito que têm os cidadãos de reccberem assistência do Estado, e a separação de podêres não é mais uma regra absoluta. A consideração dêsse aspecto estaria, entretanto, fora do dominio do direito administrativo. 


\section{A ADMINISTRAÇAO NO NIVEL DOS "LAENDER" (*) E DAS COMUNAS}

por Herbert Schirrmarter, Conselheiro do Governo no Ministério do Interior do Land de Hesse, República Federal da Alemanha.

\section{INTRODUÇ̃̃O}

Na Alemanha Federal a administração é exercida por diversos órgãos: a Federação, os "Länder", as comunas (ou municipios) e agrupamentos de comunas, além de outras entidades administrativas autônomas, tais como as corporações, estabelecimentos e fundações de direito público. A competência administrativa divide-se entre a Federação e os "Länder", em decorrência do disposto na Lei Magna, ficando entendido serem os "Länder" os titulares principais da administração. Além das tarefas que lhes são especificamente afetas, as leis federais são por êles executadas de maneira quase autônoma.

O critério para a execução das leis (federais ou não) permite ressaltar os elementos essenciais da organização administrativa. Assim é que as leis federais podem ser executadas pela própria Federação (organização dos correios e ferrovias federais), e pelos "Länder", seja nos domínios de sua competência (previdência social), seja em nome e em lugar da Federação (administração das rodovias, dos canais, etc.). Tanto as leis deferais como as dos "Länder" são de igual forma cumpridas pelas entidades de direito público e pelos outros órgãos de administração autônoma, sob a supervisão da Federeção ou de um "Land". Claro está que os "Länder" executam sua legislação própria. Não obstante, sua competência vai além dêsse limite. Os "Länder" exercem igualmente uma administração direta que, exceto em casos excepcionais, não está sujeita a qualquer intervenção por parte da Federação.

A fim de completar o quadro, deve-se acrescentar à lista dos orgãos da administração instituições que podem ser consideradas como intermediárias entre a Federação e os "Länder", ou seja, órgãos federais que executam funções no nivel dos "Länder", Citamos como exemplo o "Bundesausgleichamt".

\section{A administração dos "Länder"}

Os "Länder" possuem sua própria administração, finanças, polícia, justiça, etc. Sua atividade é autônoma, respeitados os princípios do Estado de direito democrático e da autonomia comunal que lhes impóe a Lei Magna. Nos setores em que se verifica concorrência da Federação, ou quando se trata de matéria por esta delegada, observa-se uma certa intervenção federal. Dessa forma, a Federação tem direito a elaboar, sujeita ao assentimento do Conselho Federal, regulamentos gerais de administração, jamais

(*) Estados ou provincias. 
podendo, entretanto, intervir nos casos individuais. Existe, ainda, um contrôle sôbre a legalidade da execução, e um processo especial, comportando até recurso ao Tribunal constitucional federal, pode, em casos especiais, dar origem a medidas mais concretas.

A administração dos "Länder" é exercida também por intermédio de órgãos de administração autônoma: comunas, associações de comiunas, instituições autônomas de direito público. A competência das comunas e associações de comunas é garantida pelos textos constitucionais.

A organização administrativa dos "Länder" não é uniforme. Depende das tradições e das circunstâncias históricas, de maneira que a exposição acima tão é completa. Verifica-se, no entanto, que na maioria dos casos a adıninistração é exercida em três niveis:

a) O govêrno do "Länd" e as autoridades superiores têm uma competência geral, como o Tribunal de Contas de um Land.

O yovêrno do "Länd" compõe-se de um Ministro-Presidente e de ministros. Eleito pelo "Landtag", o ministro-presidente nomeia os ministros e determina a orientação a ser seguida pela política do Land, dentro da qual agirão os ministros, sob sua própria responsabilidades perante o parlamento. O ministro-presidente não é o superior dos ministros, embora possa exorerá-los com o assentimento do parlamento, e não administra qualquer departamento. Cada ministro tem a seu cargo servişos especificos.

b) Os niveis intermediários abrangem autoridades gerais e especiais. As autoridades gerais formam uma espécie de administração departamental ("Regierugspräsidenten" e "Zezirksregiezung") com competência residual em relação aos órgãos superiores. Essa administração dividerse, ela própria, em seções e serviços segundo sua natureza e função. A atividade diária dessas seções e serviços está sujeita à autoridade do ministro competente, mas a supervisão geral está a cargo do ministro do Interior do "Land".

c) Os cantões rurais ("Landkreise") e as grandes cidades constituem, os órgãos inferiores da administração garal. Os cantões rurais são grupamentos de comunas, cujaorganização não é uniforme em todos os "Länder". Ora têm o mesmo regime das autoridades comunais autônomas (pessoal não estatal), ora reúnem órgãos autônomos e descentralizados. Nesse último caso, a autoridade hierárquica sôbre todos os serviços (comunais ou näo) pertence ao presidente do Conselho cantonal ou "Landrat". A atividade dos órgãos inferiores dos quais não fazem parte as comunas autônomas encontra-se sob a titela das autoridades intermediárias e centrais.

Deve-se salientar, à margem dessa organização, a existência de manifestações da descentralização - ou da desconcentração - por serviço sob forma de autoridades especiais, investidas de missão particular, e que atuam sob a supervisão ou autoridade do ministro competente. $\mathrm{O}$ mesmo fenômen! verifica se nos niveis intermediários e inferior, variando o regime dessas instituições, bem como o estatuto de seu pessoal, de um "Land" para outro. Êste desenvolvimento de instituições especiais tem sido discutido e criticado. Seus partidários invocam as necessidades práticas da adminis- 
tração, enquanto seus adversários afirmam dai decorrerem complicações para o cidadão e despesas administrativas suplementares. Verifica-se, sem qualquer julgamento prévio sôbre o resultado dessa controvérsia, que há uma tendência para reduzir-se a criação de tais órgãos.

\section{Administração local autônoma}

As principais instituições, nesse caso, são as comunas (sendo urbanas têm o titulo de "Stadt" ou de "Etadtkreis") e os cantões.

'Tèm sido vãos os esforços de unificação jurídica das comunas, tentados desde 1945. Há uma legislação comunal própria para cada "Lünd", possuindo características individuais. Apenas o regime jurídico relativo a pessoal é mais uniforme, porquanto encontra-se sujeito às prascrições de leis federais. Pode-se, no entanto, dividir os regimes comunais ou municipais enu três categorias entre as quais há numerosas e sutis diferenças nos "Länder":

a) O regime em que predomina o Conselho comunal ("Gemeinite" ou "Stadtratsverfassurg"), no qual o Conselho, eleito e representativo dos cidadãos, acumula funções legislativas e administrativas dos negócios da comuna. Além dos conselheiros eleitos. fazem parte do Conselho o burgomestre e seu substituto.

Esse sistema encontra-se em vigor sobretudo na Alemanha meridional, mas sob diversas formas. Em Bade-Wurtemberg, o presidente do Conselho comunal é no mesmo tempo, o chefe da administração local e tem o titulo de Burgomestre. Eleito pelo Conselho, com mandato de oito anos, é un funcionário de tempo integral, gozando de certa independência $\mathrm{cm}$ relação ao Consalho. O burgomestre é também um agente de descentralização do poder superior e preside, se fôr o caso, o Comitê de cidadãos ("Burgerausschuss"), espécie de segunda câmara, que pode ser instalada nas comunas de mais de três mil habitantes. Na Baviera, certas funçốes administrativas estão reservadas ao burgomestre e não ao Conselho por êle presidido. Na Baixa Saxônia - Alemanha setentrional - existe um regime que se aproxima dêsse sistema. Nesse caso, intervêm os conceitos estabelecidos no Decreto do Govêrno militar britânico de 1946, o qual reviu, para sua ona de ocupação, a legislação comunal alemã de 1935. Uma outra revisão foi novamente levada a cabo em 1955 , tendo tido como resultado uma transferênciz parcial dos podêres do Conselho a uma comissão administrativa ("Verwaltungsausschuss") presidida pelo Presidente do Conselho comunal, cora o titulo de burgomestre, e composta de um certo número de conselheiros comunais. Não obstante, o burgomestre não desempenha funções de natureza administrativa, as quais cabem a um funcionário ("Gereinde" ou "Stadtdirektor") eleito pelo Conseiho por um periodo de seis ou doze anos. Este funcionário tem sob suas ordens outros agentes: o tesoureiro, o arquiteto, etc. Cabe a êle dirigir a administração comunal e executar as decisões da Comissão administrativa. Constitui-se êle em agente descentralizado do poder superior e, com essa atribuição, recebe orientações diretas. A legislação adotada em 1952 pelo "Land" da Renania 
da Westfalia do Norte inspira-se nos mesmos principios em vigor na Baixa Saxônia, mas nesse caso a posição do "Gemeindedirektor" é mais in portante, em vista da ausência de comissões administrativas.

b) O regime em que predomina o burgomestre tem sua origem em conceitos franceses do início do século dezenove. O burgomestre é o chefe da administração local e, ao mesmo tempo, agente do poder central, sendo eleito pelo Conselho Comunal por oito ou doze anos e sendo funcionário de tempo integral. Esse sistema existe na Renânia-Palatinado e no Sarre, mas nesse último "Land" o burgomestre é eleito pelo Conselho, dentre seus membros, por um mandato equivalente ao dos Conselheiros ( 4 anos), devendo a eleieção ser aprovada pela autoridade de tutela. Funcionário a titulo honorífico, possui êle as mesmas prerrogativas existentes na RenâniaPalatinado. Este regime especial será, provàvelmente, objeto de uma reforma ulterior.

c) O regime em que predomina o "Magistrat" é um sistema bicameral que prevalece na Prússia e que está em vigor no Hess, em Sclewwig Holstein, e mesmo na Renânia da Westfalia do Norte. O Conselho Comunal constitui nesse caso o órgão legislativo da Comuna e o órgão de tutela administrativa de sua administração. Uma parte das atribuições dêsse Conselho, eleito pelo povo, e delegada a um Comitê ("Gemeindevorstand" ou "Magistrat"), presidido pelo burgomestre e composto de funcionários eleitos pelo Conselho, por um periodo de seis anos. O "Magistrat" é um órgào colegiado em que o burgomestre é apenas o primus inter pares, embora execute as decisões dêsse órgão e seja o chefe da administração local.

No plano cantonal, cada "Land" possui, uma organização específica. Via de regra, o órgão principal é o Conselho cantonal ("Kreistag") eleito pela população. O órgão executivo, colegiado, é o Comitê do "Kreis" ("Kreisrat" ou "Kreisausschuss") composto de membros cujas funções são desempenhadas a título honorífico. Os cantões possuem administração própria, dirigida pelo presidente do Conselho cantonal, com o titulo de "Landrat". E' êle eleito pelo povo ou pelo Conselho cantonal por um periodo de seis ou doze anos.

Cumpre ainda acrescentar algumas palavras sôbre os órgãos especiais de aḋministração. Trata-se de instituições de direito público, criadas por lei ou resultantes de uma associação voluntária de várias coletividades locais, para o cumprimento de certas missões específicas. Entre essas instituições encontram-se as associações comunais de distrito ("Bezirkskommunalverbände") e as associações que possuem uma finalidade determinada ("Zweckverbände").

\section{Conclusões}

Não se pode dizer que a organização administrativa alemã realize de maneira definitiva o sistema de administração autônoma. Prevê-se uma evolução que provàvelmente acarretará a revisão de certas noções, pois o sentide da evolução moderna é para uma concentração. Talvez um dia seja reduzido o número dos "Länder" e reorganizadas as comunas. 


\section{OS REGIMES JURIDICOS DO PESSOAL ADMINISTRATIVO}

por Gerhard Wacke, Professor da Uniniversidade de Hamburgo.

Os estrangeiros encontram certas diticuldades para compreender os regimes jurídicos que se aplicam ao pessoal administrativo da Alemanha, devido ao fato de observar-se uma certa mistura de direito público com direito pivado. Com efeito, uma parte do pessoal (atualmente cêrca de $40 \%$ ) está sujeita ao Estatuto dos funcionários ("Beamtenrecht") e por conseguinte a um regime de direito público, enquanto que outra parte, mais importante, submete-se ao direito privado (regime dos empregados e operários). Essa diferença entre "Beauntenrecht" e "Dienstrecht" está consagrada pela Lei Magna, que igualmente consagrou a existência de um "Personalrecht des oeffentlichen Dienstes" que reúne as disposições comuns às duas categorias e por conseguinte aplicáveis ao conjunto do pessoal, no mais amplo sentido do têrmo.

A história proporciona uma visão mais nítida do que é a concepção alemã. Em fins do século dezoito apareceram os primeiros regulamentos referentes à função pública, sobretudo no "Preussisches Allgemeines Landrecht" de 1794. Dai resulta que o funcionário encontra-se ligado ao Estado por relaçôes de direito público de fidelidade e de obediência. Goza de um regime jurídico especial, só podendo ser demitido mediante processo disciplinar, ocupando geralmente cargo vitalicio. Existe, além disso, um privilêgio de jurisdição. Apenas as funções materiais mais inferiores (vigia noturno, por exemplo) estavam sujeitas ao direito privado como diaristas. $\mathrm{O}$ desenvolvimento dessa categoria - que hoje em dia abrange técnicos altamente qualificados e engenheiros - teve início em meados do século dezenove, com a encampação estatal das ferrovias, que fêz com que passasse para o serviço do Estado um grande número de servidores, do qual apenas uma parte iria fazer jus ao Estatuto dos funcionários. Os continuos progressos da intervenção estatal acentuaram essa situação a tal ponto que, atualmente, os empregados e operários sujeitos ao direito privado são mais numerosos que os funcionários. As pessoas que estão sob o Estatuto, nos ministérios, concentram-se sobretudo nas administrações de natureza econômica e nas emprêsas públicas.

$\mathrm{O}$ artigo 33 da Constituição contém algumas disposições de principio relativas ao direito da função pública. Determina, em primeiro lugar, o livre acesso de todos os naturais do país a empregos públicos, de acôrdo com as aptidões e capacidade de cada um sem discriminação de qualquer espécie. Estipula, em seguida, que o exercicio das prerrogativas do poder público a título de função permanente deve ser, via de regra, confiado aos menbros do serviço público que estiverem ligados às coletividades públicas por relações de serviço e fidelidade ("Dienst-und Treueverhältnis") de direitu público. Daí resulta um outro regime aplicável a pessoas que não se enquadram neste caso, sobretudo empregados e operários de serviços públicos. Acrescenta o texto que o direito da função pública deve ser 
regulamentado levando-se em consideração principios tradicionais do funcionalismo de carreira ("Berufsbeamtentum"). A interpretação dêsse parágrafo foi objeto de controvérsia, a fim de se saber se tinha alcance geral ou limitado aos funcionários, qual o sentido a ser dado à expressão "levar em consideração", bem comn o que deveria ser incluido entre os principios tradicionais. As dúvidas foram dirimidas pela jurisprudência do Tribunal constitucional federal, o qual admitiu como base dos principios tradicionais as prescrições contidas na Constituição de Weimar.

A execução dêsses princípios foi objeto de uma legislação especifica da Federação e dos "Länder". Para a Federação a Lei de 18 de setembro de 1957 (Bundesbeamtengesetz), que dispõe sôbre os funcionários públicos, retoma os princípios constitucionais e distingue diversos tipos de funcionários: vitalício, por periodo determinado em estágio, demissivel e a título honorífico (os últimos não são remunerados). A nomeação vitalícia é a condição normal e recai nos agentes de mais de 27 anos que já tenham passado por um estágio probatório. Os de periodo determinado são os altos funcionários que ocupam cargos eletivos nas comunas. $O$ ato de nomeação para os cargos mais altos emana do chefe do Estado enquanto o-ministro nomeia para os outos cargos, esclarecendo o ato a que yrupo se destina o candidato (vitalício, por periodo determinado, etc.). Há quatro categorias de funcionários e as promoções de uma a outra estão sujeitas a regulamentos precisos (vide artigo do Sr. Sebastián Moro Serrano, abaixo). Os direitos e deveres dos funcionários encontram-se especificados no texto da referida lei (especialmente a obrigação que tem o funcionário de se colocar a serviço da coletividade e não de uma ideologia ou de qualquer grupo influente) ou nas disposições suplementares, como a lei sôbre vencimentos. Em vista de não existir até o presente um estatuto específico, que ainda se encontra em fase de elaboração, êsse regime aplica-se, por analogia, aos juizes federais.

Os "Länder" possuem uma legislação particular e por vêzes diversificada. A Federação, com o intuito de proceder a uma uniformização, promulgn normas gerais baseadas nos principios do direito federal, sôbre as quais deverão assentar-se os direitos dos "Länder", no mais tardar, a partir de $1^{\text {s }}$ de setembro de 1960 .

Ademais, há para a Federação e para os "Länder", separadamente, disposições de direito disciplinar mais ou menos uniformes, consagrando, tôdas, a intervenção de jurisdições especiais para a apreciação das faltas profissionais, a partir de um certo grau de gravidade.

Os empregados e operários de serviços públicos estão sujeitos a 111 m direito especial ("Dienstrecht"). Os empregados são muitas vêzes técnicos ou universitários que não estão investidos em função que emana do poder soberano do Estado. Trata-se de agentes sob contrato de direito privado, aos quais não se aplica, porém, o direito comum. Realmente, possurem regulamentos profissionais diferentes dos do setor privado e se aproximam mais dos do funcionalismo; seus direitos são mais precisos e sua responsabilidade - penal ou funcional - é a mesma que a dos funcionários. 
que diferencia o regime ao qual estão sujeitos do dêsses últimos é, em primeiro lugar, o fato de poderem ser dispensados de acôrdo com os regulamentos do direito privado, sem haver necessidade de processo disciplinar; os recursos a que têm direito estão no âmbito das jurisdições trabalhistas e não administrativas; as leis sociais que os regem são as do setor privado e não gozam das vantagens de natureza social (pensões mais altas, etc.) peculiares aos funcionários; e, finalmente, as funções que exercem não são permanentes, nem fixadas no orçamento. Em princípio, êsses mesmos segulamentos são válidos para os operários. Tôda a legislação referente à matéria é diferente e distinta do direito trabalhista. Trata se, além disso, de matéria na qual, em virtude da Lei Básica, a Federação tem direito exclusivo de legislação no que diz respeito aos serviços e o direito de elaborar normas gerais que se imponham aos "Länder", às comunas e instituições de direito público. Esse estado de coisas foi igualmente consagrado por decisão do Tribunal Constitucional federal. Verifica-se, pois, uma evolução para um regime diversificado, mas uniforme em cada categoria. Não obstante, há diversos problemas de principio quanto ao estatuto dos empregados e operários. Conforme já foi dito, o estatuto dêstes foi inspirado no dos funcionários, sendo idêntica grande parte de sua regulamentação. Daí resulta que uma greve de pessoal que não se enquadra na categoria de funcionário se defronta com as mesmas proibiçõcs que prevalecem para a função pública pròpriamente dita.

A lei de disposições gerais sôbre o pessoal público ("Gesamt-Personalrecht") baseia-se igualmente na Lei Magna. Esta faz, várias vêzes, alusão aos direitos dos "agentes de serviços públicos" ou das "pessoas investidas em função pública", sobretudo em seus artigos 34, 36, 131, 132, 137 e 139. Os regulamentos são, pois, uniformes (responsabilidade de função, respeito à divisão geográfica de origem dos funcionários federais e principio do recrutamento regional para os serviços descentralizados, etc.). Há outros domínios nos quais tais regulamentos são aplicáveis às duas categorias de agentes: no direito orçamentário, no direito de representação do pessoal superior que equivale, no setor privado, ao dos Conselhos de emprêsa, etc. Nesse último domínio da representação há possibilidades para o pessoal de cooperar na gestão dos negócios sociais e relativos ao pessoal nos serviços públicos. A organização dos conselhos é feita de acôrdo com os grupos, isto é, há um regime especifico para os funcionários, os empregados e os operários. Os recursos que porventura possam surgir na aplicação prática recaem na alçada da jurisdição administrativa e não dos tribunais trabalhistas.

A exposição que acaba de ser feita mostra a complexidade do regime alemão, só explicável em face do desenvolvimento do direito. O apêgo ao conjunto das tradições jurídicas é que explica o fracasso das tentativas para unificação do direito da função pública, especialmente as que foram feitas pelas autoridades militares em 1946. 


\section{CARREIRAS ADMINISTRATIVAS E PROMOÇOES NA FUNÇÅO PÚBLICA FEDERAL}

por Sebastián Moro Serrano, da Secretaria Geral técnica da Presidência do Govêrno, Madri, Espanha.

\section{INTRODUÇÃO}

O funcionalismo de carreira viu-se sob severas criticas na Alemanha após as duas guerras mundiais, notadamente após 1945. O que se the criticava, principalmente, era sua docilidade ao regime, o recrutamento para os seus quadros superiores ùnicamente entre juristas e os seus privilégios burocráticos. Assim sendo, tentou-se submetê-lo, em vão aliás, ao direito trabalhista comum. A Lei Básica de 1949 consagrou o direito tradicional da função pública na medida em que o mesmo se adaptava à ordem democrática. Foi mantido o conceito das relações de serviço de direito púbiico. A lei de 14 de julho de 1953, que criou o estatuto dos funcionácios (Bundesbeamtengesetz), desenvolveu êsses principios. Essa legislação possui, sobretudo, uma disposição complementar referente às carreiras na administração federal ("Bundeslaufbahnverordnung") que apresenta especial interêsse. Consagra ela certas modificações importantes na legislação constitucional, possibilitando principalmente o recrutamento externo.

\section{II - CONCEITO E ESTRUTURA DA CARREIRA}

Define-se carreira como uma série de cargos administrativos, dentro dos quais um funcionário pode evoluir desde sua entrada em serviço até sua aposentadoria. O estatuto dos funcionários apresenta para cada carreira três etapas: 1) funcionários demissiveis, que vai desde a admissão provisória até o fim do período dito "serviço de preparação"; 2) funcionários em estágio probatório e, finalmente; 3) funcionários vitalícios, a partir da nomeação definitiva.

O Estatuto dos Funcionários ("Bundesbeamtengesetz") divide as carreiras em quatro categorias: "Einfacher Dienst" (serviço simples), "Mittierer Dienst" (serviço médio), "Gehobener Dienst" (serviço principal) e "Höherer Dienst" (serviço superior). Essas categorias podem, por sua vez, ser subdivididas e assim é que na "Höherer Dienst", por exemplo, encontramos o Serviço Superior Técnico da Administração Geral do Estado, que compreende carreiras como a de Serviço Técnico de Construção e Serviço Superior de Minas.

Os chefes hierárquicos têm competência para regulamentar suas carreiras especificas, expedindo disposições especiais, mediante autorização prévia do ministro do interior ou das finanças. 


\section{ORIGEM DAS RELAÇÕES DE SERVIÇO}

Os candidatos considerados aptos após o "serviço de preparação" são nomeados em função do mérito e levando-se em consideração as disposições legais referentes à matéria (ex.: preferência a veteranos de guerra). Devem em seguida dar prova de capacidade durante o estágio probatório.

No que diz respeito ao recrutamento externo, de que falaremos abaixo, o processo é diverso porquanto os candidatos, sem passar pelo "serviço de preparação", são admitidos em estágio probatório após avaliação de suas qualificações pela Comissão Federal do Pessoal.

A adinissão ao estágio probatório para os três primeiros grupos é feita mediante a apresentação de um certificado de estudos, enquanto que para o quarto grupo os candidatos devem submeter-se a um exame de Estado ("Staatsexamen").

Existe em cada "Land" uma Direção de Formação Profissional que orienta os trabalhos e julga os resultados dos carididatos recém-nomeados. No término do ciclo de formação ou aperfeiçoamento, o diretor apresenta um relatóriu sühre os candidatos, cujas notas vão de "muito bem" a "insuficiente". E' em função dêsses relatórios que a administração permite ou impede que o candidato preste exame para admissão definitiva. Os candidatos à categoria superior têm o título de "Referendar", enquanto que os candidatos dos três outros grupos são denominados "Aspirant".

A nomeação definitiva só é feita após o estágio probatório, e os candidatos não fodem ter mais de 32 anos para as três primeiras categorias e nem mais de 35 anos para a categoria superior.

\section{III - ORGANIZAÇÃo DAS CARREIRAS}

A. "Einfacher Dienst" (serviço simples): Os candidatos, com idade minima de 16 anos e máxima de 35 ( 40 anos para inválidos de guerra) devem ter o curso primário e possuir, se fôr o caso, os conhecimentos técnicos necessários. O "serviço de preparação" tem uma duração de seis meses e termina por um exame. O estágio probatório é de um ano e pode ser prorrogado mediante decisão, se fôr o caso, do chefe hierárquico.

B. "Mittlerer Dienst" (serviço médio): O limite de idade para essa categoria é de 30 anos ( 40 para inválidos de guerra). Por outro lado, os funcionários que contam 10 anos de serviço e que ainda não ultrapassaram 40 anos de idade também podem apresentar sua candidatura a postos superiores desta categoria. As exigências de educação são idênticas às exigidas para o "seııviço simples". O "serviço de preparação" é neste caso de um ano e o estágio probatório de no minimo dois anos e no máximo três.

C. "Gehobener Dienst" (serviço principal): São as seguintes as condições de acesso a esta categoria : 18 a 30 anos (40 para inválidos de guerra) ou 10 anos de serviço sem ter ultrapassado 40 anos de idade, estar 
de posse de um certificado de ensino secundário e para as funções técnicas de um diploma de arquitetura, de engenharia ou de uma instituição técnica superior.

O "serviço de preparação" dura três anos. Durante êsse período, os candidatos podem beneficiar-se de uma licença de um ano para seguir cursos em uma escola técnica. Ao terminar o "serviço de preparação" os candidatos prestam um exame que lhes permite passar para o estágio probatório ou, em caso de reprovação, para o Mittlerer Dienst.

D. "Höherer Dienst" (serviço superior): Os candidatos que tiverem no máximo 32 anos, 35 para as carreiras técnicas e 40 anos se forem inválidos de guerra, devem possuir diploma de ensino superior. O "serviço de preparação" dura um mínimo de 3 anos, após o que é prestado um exame, seguindo-se um estágio probatório de 3 anos.

Em cada uma das três categorias mais altas, os membros da categoria inferior tên uma possibilidade de ingresso: Assim é que um funcionário do "serviço simples" pode ter acesso ao "serviço médio", caso der provas de capaciclade e após submeter-se a um estágio probatório de, pelo menos, um ano. Un membro do "serviço médio" pode entrar para o "serviço principal" após quatro anos de serviço, mediante estágio de três anos e aprovação em exame. Finalmente, um funcionário do "serviço principal" pode ter acesso ao "serviço superior", contanto que desempenhe função que lhe permita êsse acesso, tenha 15 anos de serviço e menos de 58 anos de idade, já tenha desempenhado, com êxito, funções da categoria superior e tenha sido aprovado nos exames de promoção. O período de preparação é de três anos, mas pode ser reduzido se, no exercício de suas funções anteriores, o candidato já tiver adquirido os conhecimentos suficientes. Por outro lado, um candidato fnde não ser obrigado a prestar exame, no caso de já ter passado por tódas as etaaps de sua carreira e tiver mais de 45 anos de idade.

\section{IV - RECRUTAMENTO EXTERNO}

Os randidatos de fora, com um mínimo de 32 ou 35 anos e um máximo de 50 anos, estão em pé de igualdade com os candidatos comuns. Não obstante, a lei lhes interdita certas carreiras para as quais exigem formação, aprendizagem e exames especiais. Entram para o funcionalismo público sem passar pelo "serviço de preparação" e sua capacidade é apreciada pela Comissâo Fiederal do Pessoal. O estágio probatório para êsses funcionários é de três anos para os serviços simples e médio, de quatro anos para o serviço principal e de cinco anos para o Serviço Superior.

\section{V - AVALIAÇÃo DE FUNCIONÁRIOS}

A capacidade e o rendimento dos funcionários devem ser avaliados cada três anos, assim como cada vez que o chefe hierárquico fôr transferido. A avalią̧ão compreende a inteligência, o comportamento, a capacidade, a eficiência e o estado de saúde. Cada relatório faz também uma apreciação geral e uma análise das possibilidades de promoção dos funcionários. 


\section{VI - TREINAMENTO}

Sob a supervisão e estímulo dos chefes, têm os funcionários a obrigação de se aperfeiçoarem no serviço, a fim de melhor executar as tarefas que lhes são afetas. Muitas vêzes o funcionário é promovido em função do treinamento adıuuirido em serviço.

\section{VII — PROMOÇÃO}

A promoção é decidida pelo chefe hierárquico, baseado no mérito. O funcionário não possui qualquer direito subjetivo à promoção, da mesma forma como não o tem à nomeação definitiva.

Cumpre observar, nessa ordem de idéias, um princípio muito importante em matéria de promoção: em nenhum caso é permitido pular classes, isto é, o acesso vertical deve ser feito degrau por degrau.

Outros regulamentos impõem certas limitações à promoção. Assim é que um funcionário não pode ser promovido durante o estágio probatório, ou antes de decorrido um ano após a nomeação definitiva, nem durante os três últimos anos antes de completar o limite de idade.

A Comissão Federal do Pessoal pode abrir certas exceções por razões sérias. Ademais, a importância de certas funções exige, mais que qualquer outro critério, a consideração da antiguidade e da experiência.

\section{A JURISDIÇÃO ADMINISTRATIVA}

por Carl-Hermann Ule, Professor da Universidade de Heidelberg, antigo Reitor da Escola Superior de Ciências Administrativas de Spira.

\section{1 - A LEI BÁSICA E AS JURISDIÇÕES ADMINISTRATIVAS}

A estrutura atual da jurisdição administrativa foi estabelecida após o término da última guerra mundial, tendo sido elaborada em certas regiōes entre 1946 e 1948, mas foi influenciada sobretudo pelos princípios constantes da Lei Básica de 1949. Esses principios afastam-se dos que foram adotados em 1919 pela Constituição de Weimar, principalmente por consagrarem a separação da jurisdição administrativa da administração, sua integração ziutônoma no poder judiciário e a diferenciação de suas atribuições das dos tribuıais ordinários. $E^{\prime}$ êste o resultado das novas tendências do direito público alemão.

A iurisdição administrativa é exercida no nivel da Federação e dos "Länder". A Lei Básica determina, em seu artigo 96, a instituição de tribunais federais superiores para os domínios da jurisdição de direito conıum, da jurisdição administrativa, da jurisdição fiscal e da jurisdição trabalhista e social. A Federação poderá, ainda, criar tribunais disciplinares 
federais fara processos disciplinares contra juizes e funcionários federais (inclusive militares). Em decorrência dêsse artigo foram criados o Tribunal Adninistrativo Federal, como órgão de revisão e de recursos em matéria administrativa, com sede em Berlim; o Tribunal Federal de Finanças, de Munique, para cuidar de matéria fiscal; o Tribunal Federal Social, em Cassel, para seguro social; e o Tribunal Disciplinar Federal, também em Berlim, como órgão de apelação para causas de natureza disciplinar dos funcionários federais e dos tribunais militares. Trata-se, em princípio, de órgãos de apelação ou de revisão, conforme o caso, intervindo apenás excepcionalmente como órgãos de primeira instância.

O prublema da competência legislativa em matéria de organização da jurisdiçâo administrativa foi matéria controversa, devido ao fato de a Federação e os "Länder" terem entrado em choque, mas atualmente é aceita por unanimiadade a competência federal. Esta solução não é, porém, satisfatória, po:qquanto a organização das jurisdições administrativas varia, às vêzes de maneira acentuada, de um "Land" para outro. Foi aprovado, em fins de 1952, pelo Govêrno federal, um projeto de uniformização geral ("Entwurf einer Verwaltungsgerichtsordnung"), elaborado por um grupo de estudos̀ constituido pelos Ministros do Interior dos "Länder" e por representantes da Associação dos Presidentes dos Tribunais administrativos. O projeto ainda não entrou em votação no Parlamento, mas tudo indica que secá votado até o fim do corrente ano. Se entrar em vigor em $1^{\circ}$ de janeiro próximo, porá fim às confusões que ora se verificam. E' a êsse projeto. que nos referimos abaixo, ao falarmos do "projeto de reforma".

Do ponto-de-vista da evolução histórica, vale assinalar que as primeiras. jurisdiçôes administrativas alemãs, do século XIX, foram inicialmente instituídas pela administração e não no poder judiciário. Certas instituições. dêss e tipo surgiram no sul e no centro do país e foram inspiradas no exemplo francês. A partir de 1863, porém, a jurisdição administrativa, sob a influência dos conceitos defendidos por von Mohl e von Gneist, tornou-se pouco a pouco autônoma, diferente dos tribunais ordinários mas também da administração, ccnceito êsse cuja concretização se manifesta na estrutura atual.

A Constituição de Weimar tinha concebido as jurisdições administrativas em função da limitação de sua competência por uma enumeração exaustiva, constituindo exceção a cláusula geral, admitida hoje em dia. Reconhecia a Constituição aos membros das jurisdições administrativas a independência de magistrados, mas limitava a competência dos tribunais administrat:vos em benefício dos tribunais ordinários nas causas de natureza periniária, mesmo com caráter de direito público. Essa restrição provinha $\mathrm{em}$ parte da inadaptação às necessidades das jurisdições administrativas dá época.

Outra situação se apresentou à constituinte de 1949, que admitiu a cláusula geral de competência para as jurisdições administrativas, com exceção do que diz respeito a recursos em matéria de desapropriação por utilidade pública e à apreciação da responsabilidade funcional dos agentes públicos, casos que se enquadram na competência dos tribunais ordinários. E' certo que o artigo 19 , alínea 4, da Lei Básica estabelece a possibilidade 
de qualquer pessoa que se considerar lesada em seus direitos pelo poder público interpor recurso jurisdicional. Esse artigo determina, salvo disposição em contrário, a competência dos tribunais ordinárias para conhecer da matéria. Mas em vista da cláusula geral de competência das jurisdições administrativas, seu caráter residual é apenas teórico e a vantagem dos tribunais ordinários puramente formal.

\section{II - ESTRUTURA DAS JURISDIÇÕES ADMINISTRATIVAS}

Se a leọislação dos "Lä1der" é pouco uniforme a êsse respeito, quase não varia, forém, no que se refere a princípios: as jurisdições administrativas comportam dois graus de jurisdição do exame de atos administrativos não discricionários, quer de fato quer de direito. A criação do Tribunal Adninistratıvo Federal veio acrescentar uma instância de revisão, que não constitui uma instância suplementar porquanto julga apenas questões de direito, isto é, a obediência das decisões ao direito federal.

A composição das jurisdições também é variável. Os tribunais de instâncias inferiores são geralmente compostos de juizes de carreira e de membros não profissionais e não remunerados. $O$ mesmo principio se aplira aos Tribunais superiores, ficando entendido que nêles se encontra a maioria de juizes profissionais. A questão da composição das jurisdições é aliás bastante controversa.

A organização das jurisdições administrativas baseia-se na dos tribunais ordinários, enquanto que o processo que lhes é aplicável apresenta estreitas relações com o processo administrativo não-contencioso (vide artigo do professor Spanner). De fato, se a individualização das jurisdições administrativas permite diferenciá-las da administração, também é certo que essa diferença é as vêzes muito pequena. A ação de anulação apresenta-se com uma espécie de apelação interna e esta observação mostra-se em tôda sua ir portância se a relacionarmos às modalidades do processo não contencioso anterior. Observa-se então que um mesmo caso pode passar por seis instâncias (três não contenciosas e três jurisdicionais) e que muitas vêzes há multiplicação inútil de recursos, o que muito complica as coisas. O projeto de reforma prevê uma sımplifıação dêsse processo.

\section{III - DO RECEBIMENTO (CONHECIMENTO) DO RECURSO ADMINISTRATIVO}

Mediante a aplicação da cláusula geral de competência, qualquer contestação a umi ato administrativo pode ser objeto de intervenção da jurisdição administrativa. A divisão da competência com os tribunais ordinários opera-se na base do critério de direito privado e de direito público, com exceção de litígios constitucionais. Conforme já dissemos, certas matérias de direito público (ação de indenização contra agentes do poder público que tenham violado seus deveres funcionais em detrimento de terceiros, e As contestações em matéria de desapropriação) são retiradas da competência das jurisdições administrativas para a dos tribunais civis. Por outro lado, 
as contestaşôes de naturezá pecuniária que possam surgir entre os podêres públicos e os funcionários, e que tradicionalmente eram da competência do jui ? civil, foram transferidas ao juiz administrativo.

Na organização da proteção jurídica por via administrativa contenciosa, - recurso de anulação há muito tempo desempenha papel essencial. Pode ser exercido contra todos os atos administrativos das autoridades federais e dos "Länder", das diversas autoridades públicas e comunais, e isto tanto no dorrinio da "administração de serviços ou de gestão" como na de "intervenção". Verifica-se a importância que tem a noção de ato administrativo como critério para o conhecimento de recursos, não sendo fácil dizer quando uma medida administrativa possui êsse caráter. Segundo a teoria administrativa clássica - e a famosa definição de Otto Mayer - o ato administrativo é um ato da aitoridade púbilica, mediante o qual uma autoridade administrativa decide por meio de autoridade, e juridicamente, um caso individual. Antes de 1948, a lei ignorava essa noçäo, definida no Decreto n? 165 do Govêrno militar britânico (vide artigo do professor Spanner), e tornada precisa pela jurisprudência e pela doutrina. Apesar disso, nem sempre é tácil determinar o que é um ato administrativo. A noção, bastante ampla, comporta entretanto certas restrições. Excluem-se sobretudo as medidas puramente materiais, exceto em questão de função pública. Não se trata, necessàriamente, de qualquer medida relativa à situação jurídica de uma pcssoa ou decorrente de uma relação de subordinação à autoridade. A questão continua controvertida em vários setores. A dificuldade é aumentada pelo fato de um ato administrativo poder ter a forma de um ato de ‘lireito frivado, o que ocorre muitas vêzes no dominio do direito administrativo da economia ou da concessão de subvenções públicas, embora se trate, nesse setor, de manifestações do poder discricionário. Isso mostra bem claramente que a interpretação da noção de um ato administrativo deve ser feita de maneira ampla e de acôrdo, aliás, com os princípios enunciados no artigo 19, alínea 4 da Lei Básica (vide acima).

\section{IV - PRINCIPAIS PROBLEMAS DE PROCESSO}

Se o tecurso de anulaçãc ainda mantém uma importância fundamental, não possui mais a posição exclusiva que ocupava outrora. A seu lado há dois tipos cie ações : ações de contestação de direito ("Feststellungsklage") e sobretudo ação de execução ("Leistungsklage") em caso de omissão ou silêncio da administração. O recurso de anulação ataca a ilegalidade de um ato, enquanto que uma ação de execução (também chamada "Vornahmeklage" ou "Verpflichtungsklage") visa a obrigar a administração a algum ato, ou a permitir que alguém pratique um ato, ou, ainda, a impedir que a administração pratique determinado ato. E' grande a importância dessas. ações en aireito administrativo econômico. A fim de poder dar entrada em uma dessas ações o interessado deve justificar a necessidade de proteção. legal e ter um interêsse na ação. Não existe na Alemanha a ação dita "popular", isto é, aquela que autoriza qualquer pessoa a dar entrada em. uma ação contra um ato nurivo. 
O prccesso seguido perante jurisdições administrativas não difere do que é utilizado em tribunais ordinários, exceto em dois aspectos : exige-se mais frequientemente um processo administrativo prévio e o processo é inquisitorial. O processo prévio não se aplica a não ser em caso de recurso de anulação, enquanto que a exúusição dos fatos e das provas é geral, dispondo a jurisdição, nesse dominio, de amplas prerrogativas. A apresentação de provas é direrente do que se observa no processo civil, admitindo-se a apresentação de prova material. As provas variam de acôrdo com as ações. Assim, na ação de execuçãc, o interessado deverá provar a legitimidade de sua reivindicação.

O processo de primeira instância termina por uma sentença, a menos que a causa seja resolvida de outra maneira (por ter sido tornado sem efeito o ato contestado, por acôrdo amigável, por desistência, etc.). Pode-se apela: dessa sentença a uma jurisdição superior. A decisão dessa última pode ser levada ao Tribunal Administrativo Federal, que se constitui em uma instân ia de revisão para casos de violação do direito federal ou vício de processo. Com exceção de caso onde houver vício de processo, exige-se o consentimento prévio da jurisdição de onde emana a decisão da qual se apela, para conhecimento da ação. $\mathrm{Na}$ eventualidade de não ser dado consentimento, pode-se interpor recurso sôbre tal ponto perante o Tribunal Administrativo Federal. Embora geralmente só possa ser apresentada apelação baseada em questões de direito, a jurisdição administrativa federal vê-se a bracos com um númcio enorme de casos, sendo que em fins de 1958 haviı 4.000 causas atrasadas. Como há sempre novas causas, o atraso pode ser estimado em dois anos. Sendo idêntica a situação nas outras jurisdiçôes, tornam-se necessários vários anos para a conclusão de uma açãn. A reforma prevista tende a reduzir êsse prazo, mas se se desejam resultados concretos parece ser necessária uma reorganização da estrutura das jurisdiçôes.

A eficacia real da proteção jurídica não se baseia apenas na concessão de unı direito de recurso, mas no fato de se saber se tem êle efeito suspensiro sôbre as decisões recorridas, se pode dar origem a medidas provisórias (ação de execução) e à execução de sentenças jurisdicionais forçando a adıninistração a um ato positivo.

Constitui regra terem efeito suspensivo, salvo em matéria fiscal, as formas de direito do processo administrativo não contencioso (oposição, recurso ou contestação), assim como os recursos de anulação. A administraçăo pode, no entanto, ordenar a execução se assim o exigirem interêsses superiores, mas não com base apenas no interêsse público. Mediante solicitaçâo do interessado, a jui isdição pode sobrestar a execução. Não há opinião unânime sôbre se essa decisão de sobrestar pode ser tomada antes da apresentação de um recurso, mas é a opinião mais admitida e que será consagradi pela legislação projetada. Em caso de manifesta ilegalidade do ato $a$, ordem pública inı̂ne a medida. Em principio, essas regras não valem para os atos normativos de direito que, pela sua própria natureza, são de execução imediata (exemplo, demissão de funcionário). Entretanto, a doutrina $e$ a jurisprudência admitem um certo efeito suspensivo do recurso 
contra tais atos. A administração tentou contornar êsse obstáculo - especialmente em matéria de habitação - procedendo a uma execução imediata, mas as jurisdições se opuseram a essa atividade intempestiva. ' $\mathrm{E}^{\prime}$ óbvio que essas regras não são válidas para ação de contestação de direito ou ação de execução. Nâo obstante podem, no último caso, surgir medidas provisórias segundo as espécies, que não prejulgam a decisão final.

A questão da execução das decisões jurisdicionais surge no caso da ação de execução. As sentenças são por si mesmas executáveis, mas como forçar a administração a tomar medidas positivas ? O problema dos meios de coerção que se apresentam ao juiz nessa eventualidade não está regulamentado no direito atual, mas o estará na legislação futura. Pode-se duvidar da utilidade de uma tal determinação, porquanto em um Estado de direito uma decisão da justiça deve ser cumprida pela administração sem que seja necessário recorrer a medidas coercitivas.

\section{$\mathrm{V}$ - CONCLUSÕES}

As novas jurisdições administrativas alemãs têm-se mostrado eficazes e contribuem para a realização dos principios do Estado de direito em matéria administrativa. Seu funcionamento poderia, sem dúvida, ser melhorado, mas a sua concepção é bastante satisfatória e sua organização permite associar à justiça administıatıva especialista qualificados como assessôres a título honorifico. Devetios também desejar que não tenham êxito as tendências atuais para uma modificação do estatuto das jurisdições administrativas no que se refere a sua independência para com a administração e os tribunais ordinários. 